\title{
Airborne Particulate Matter from Sparkling Fireworks
}

\author{
Haruki Shimazu ${ }^{1}$ \\ ${ }^{1}$ School of Science and Engineering, Kindai University, Osaka, Japan \\ Correspondence: Haruki Shimazu, School of Science and Engineering, Kindai University, Osaka, 577 8502, Japan. \\ Tel: 81-6-4307-3559. E-mail: hshimazu@civileng.kindai.ac.jp
}

Received: January 9, 2017

Accepted: March 7, $2017 \quad$ Online Published: March 31, 2017

doi:10.5539/ep.v6n1p19

URL: https://doi.org/10.5539/ep.v6n1p19

\begin{abstract}
The present study examines the emission levels of particulate matters (PM) from sparkling fireworks and to know the emission characteristics of PM. Particulate matter $<2.5$ microns (PM2.5) and suspended particulate matter (SPM) were determined while burning six brands of sparkling fireworks. The average PM concentrations before burning were levels of $10 \mu \mathrm{g} / \mathrm{m}^{3}$, but the average concentrations after burning were $741 \mu \mathrm{g} / \mathrm{m}^{3}$ for PM2.5 and $810 \mu \mathrm{g} / \mathrm{m}^{3}$ for SPM. The mean ratio of the concentrations of PM2.5 and SPM after burning in all of the sparkling fireworks was 0.890 . The emissions per firework ranged from $6.5 \mathrm{mg}$ to $151 \mathrm{mg}$ for PM2.5, and from $7.1 \mathrm{mg}$ to $160 \mathrm{mg}$ for SPM. The means of the emissions per combustible amount of the firework ranged from 0.017 to $0.066 \mathrm{mg} / \mathrm{mg}$ for PM2.5, and from 0.018 to $0.071 \mathrm{mg} / \mathrm{mg}$ for SPM. The influences of the burning time, burning rate and combustible amount of the fireworks on the PM emissions were investigated. As a result, PM2.5 and SPM emissions tend to increase with the burning rates. This suggests that the burning rate of firework have an influence on the PM emissions.
\end{abstract}

Keywords: particulate matter $<2.5$ microns (PM2.5), suspended particulate matter (SPM), sparkling fireworks

\section{Introduction}

Air pollution and its human health effects are of great concern to the general public. In particular, the problem of airborne particulate matter (PM) has received much recent attention. PM with a size of less than about $10 \mu \mathrm{m}$ can settle in the bronchi and other parts of the lungs. These particles also contain toxic heavy metals and hazardous organic pollutants (Bi, Sheng, Peng, Chen, \& Fu, 2005; Vasilakos et al. 2007). Several epidemiological studies have shown that an increase in airborne PM is associated with respiratory symptoms, lung cancer, cardiovascular diseases and mortality (Ackermann-Liebrich et al. 1997; Pope et al. 2002; Du, Xu, Chu, Guo, \& Wang, 2016). International Agency for Research on Cancer (IARC) designates PM a Group 1 carcinogen (IARC, 2016).

Owing to its high toxicity, PM is regulated by most governments. The US Environmental Protection Agency sets National Ambient Air Quality Standards (NAAQS) for PM2.5 and PM10 under the Clean Air Act (EPA, 2013). PM2.5 is defined as particles that pass through a size-selective inlet with a $50 \%$ efficiency cut-off at $2.5 \mu \mathrm{m}$ aerodynamic diameter, and PM10 is defined as those that pass through a size-selective inlet with a $50 \%$ efficiency cut-off at $10 \mu \mathrm{m}$ aerodynamic diameter. The daily average guideline values for PM2.5 and PM10 in the current NAAQS are 35 and $150 \mu \mathrm{g} / \mathrm{m}^{3}$, respectively. The European Union has also established European emission standards, which include limits for particulates in the air (EC, 2016). The annual average guideline values for PM2.5 and PM10 in the current European air quality standards are 25 and $40 \mu \mathrm{g} / \mathrm{m}^{3}$, respectively. Other governments, including those of Japan, China, Australia and Canada, also set air quality standards regarding PM. PM originates from a variety of natural sources, such as volcanoes, forest fires, dust storms and sea spray. Human activities, such as the burning of fossil fuels in vehicles, power plants and industrial processes, also generate considerable amounts of PM (Gertler 2005; Srimuruganandam \& Shiva Nagendra, 2012; Karagulian et al. 2015). Many studies have shown that PM concentrations are high in urbanized areas, where the majority of these man-made sources are concentrated (Roosli et al. 2001; Gomiscek et al. 2004; Yin \& Harrison, 2008; Mues et al. 2013).

One of the many man-made sources of PM is burning fireworks. Wehner, Wiedensohler, and Heintzenberg (2000) determined the aerosol size distribution and mass concentration during the Millennium fireworks in Leipzig, Germany. The range of the size distribution and mass concentration of the aerosol was higher during than before and after the fireworks. Several studies have shown that fireworks contribute to increased PM concentrations and 
increased contents of Ba and $\mathrm{Sr}$ in the airborne particles (Wang, Zhuang, Xu, \& An, 2007; Vecchi et al. 2008; Barman, Singh, Negi, \& Bhargava, 2009; Camilleri \& Vella, 2010). Seidel and Birnbaum (2015) also studied PM2.5 observations at 315 sites across the US between 1999 and 2013 to estimate the effects of Independence Day fireworks. They showed that hourly PM2.5 concentrations during the fireworks were higher than those on control days, and that sites adjacent to firework displays showed a $48 \mu \mathrm{g} / \mathrm{m}^{3}(370 \%)$ increase in the 24-h-average PM2.5 concentration. However, little is known about the PM emission characteristics of burning fireworks. This study therefore examined the PM emission characteristics of six brands of sparkling fireworks. The primary objective of this work was to determine the amount of PM emitted from the fireworks. The secondary objective was to understand the influence of the burning time, burning rate and combustible amount of the fireworks on the PM emissions.

\section{Materials and Methods}

Six brands of sparkling fireworks were investigated in this study. The weights of each brand of firework before and after burning and their burning times were measured five times. The results are shown in Table 1 . The mean weights of the fireworks ranged from 203 to $7920 \mathrm{mg}$ before burning and from 83 to $5280 \mathrm{mg}$ after burning. The concentrations of PM2.5 and suspended particulate matter (SPM) in air samples before and after burning each brand of firework were measured six times. SPM is defined as particles that pass through a size-selective inlet with a $100 \%$ efficiency cut-off at $10 \mu \mathrm{m}$ aerodynamic diameter. SPM is an air quality standard peculiar to Japan, and corresponds to PM6.5-7.0.

Table 1. Sparkling firework weights before and after buring, and their burning times

\begin{tabular}{lcccc}
\hline & \multicolumn{3}{c}{ Firework weights $(\mathrm{mg})$} & \multirow{2}{*}{ Burning times (s) } \\
\cline { 2 - 4 } & Before burning & After burning & Difference & \\
\hline Brand A & $203 \pm 36$ & $83 \pm 10$ & $121 \pm 43$ & $30.8 \pm 3.7$ \\
Brand B & $2154 \pm 28$ & $1799 \pm 16$ & $354 \pm 13$ & $68.6 \pm 1.6$ \\
Brand C & $4540 \pm 49$ & $2460 \pm 162$ & $2080 \pm 160$ & $59.2 \pm 11.6$ \\
Brand D & $4940 \pm 242$ & $2620 \pm 147$ & $2320 \pm 98$ & $32.4 \pm 1.0$ \\
Brand E & $7920 \pm 160$ & $5280 \pm 214$ & $2640 \pm 301$ & $78.4 \pm 10.3$ \\
Brand F & $7780 \pm 232$ & $5020 \pm 75$ & $2760 \pm 162$ & $43.8 \pm 1.9$ \\
\hline
\end{tabular}

Note. The values show arithmetic means $\pm \mathrm{SD}(\mathrm{n}=5)$. The difference means the firework weight difference between before and after burning.

A high-volume air sampler (HV-500R; Sibata Scientific Technology Ltd., Souka, Japan) was used to collect PM2.5 and SPM in air. This instrument is a compact and transportable sampler used for industrial hygiene purposes, and collects suspended airborne particles at a suction flow rate of $100-800 \mathrm{~L} / \mathrm{min}$. It can be used for various measurement types by combining options, inertial-impact distributors or shuttle tubes. Two air samplers were used in this study; one was fitted with a PM2.5 distributor and the other with an SPM distributor.

Sampling room 1 was used for the experiments with Brands A, B and E. The sampling room was $2.5 \mathrm{~m}$ high, 5.3 $\mathrm{m}$ long and $5.0 \mathrm{~m}$ wide (approximately $66 \mathrm{~m}^{3}$ ). Sampling room 2 was used for the experiments with Brands C, D and F, and was $2.7 \mathrm{~m}$ high, $6.9 \mathrm{~m}$ long and $6.8 \mathrm{~m}$ wide (approximately $126 \mathrm{~m}^{3}$ ). Each firework was burned in the center of the room. The numbers of burned fireworks were two for the experiments in sampling room 1 and one for sampling room 2. The two high-volume air samplers were set at a height of $60 \mathrm{~cm}$ above the floor on the diagonal line of the room about $1 \mathrm{~m}$ from the center. The larger sampling room 2 was used for Brands $\mathrm{C}, \mathrm{D}$ and $\mathrm{F}$ because the maximum PM2.5 concentration is estimated to reach levels of $10000 \mu \mathrm{g} / \mathrm{m}^{3}$, and the experimental environment is not good for our health.

To remove PM2.5 and SPM from the sampling rooms before burning the fireworks, the air was purified by suction using the two high-volume air samplers. The suction rates and times were $500 \mathrm{~L} / \mathrm{min}$ for $2.0 \mathrm{~h}$ for the experiments in sampling room 1 , and $400 \mathrm{~L} / \mathrm{min}$ for $2.0 \mathrm{~h}$ for the experiments in sampling room 2 . The maximum concentrations of PM immediately after burning the fireworks in sampling room 2 were expected to be high. A lower suction rate was used in sampling room 2 than in sampling room 1 because the air samplers stopped during Brand E experiments in sampling room 1 owing to high $\left(7000 \mu \mathrm{g} / \mathrm{m}^{3}\right)$ PM levels. After the initial air purification, one sparkling firework was burned in the sampling room. For the experiments in sampling room 
1, about $60 \mathrm{~m}^{3}$ air was collected with each air sampler at an initial rate of $500 \mathrm{~L} / \mathrm{min}$. For the experiments in sampling room 2, about $110 \mathrm{~m}^{3}$ of air was collected with each air sampler at an initial rate of $400 \mathrm{~L} / \mathrm{min}$.

Quartz fiber filters (QR-100; Advantec, Tokyo, Japan) were used in the high-volume air samplers to collect PM2.5 and SPM. The fiber filter was placed in a dry box (165CDB; Toyo Living Co., Ltd., Yokohama, Japan) for $30 \mathrm{~min}$ before use. The initial mass of the filter was measured using an electronic balance (Sartorius TE214S; Data Weighing Systems, Illinois, USA) after removing it from the dry box. Then, the filter was placed into a stainless steel petri dish and brought to the experimental room. After the sampling was complete, the filter was returned to the dry box for $30 \mathrm{~min}$ and then weighed to determine its final mass. The amounts of PM2.5 and SPM were calculated based on the difference between the filter masses before and after sampling. For the experiments in sampling room 1, one filter was used for Brand A, one for Brand B and four for Brand E. In sampling room 2, five to seven filters were used for Brand C, seven to eight for Brand D and four to five for Brand F.

\section{Results and Discussion}

PM2.5 and SPM were measured in the sampling rooms before and after burning the sparkling fireworks. The results are shown in Table 2. The average PM2.5 concentration before burning was $15.8 \mu \mathrm{g} / \mathrm{m}^{3}$ and the PM2.5 concentrations ranged from 2.1 to $45.9 \mu \mathrm{g} / \mathrm{m}^{3}$. The average SPM concentration before burning was $20.0 \mu \mathrm{g} / \mathrm{m}^{3}$ and the SPM concentrations ranged from 5.0 to $48.0 \mu \mathrm{g} / \mathrm{m}^{3}$. The average concentration levels were almost the same as the annual average ambient concentrations in Japan. The mean ratio of the concentrations of PM2.5 and SPM before burning was 0.801 , and the correlation coefficient between the PM2.5 and SPM concentrations before burning was $0.825(\mathrm{p}<0.01)$, as shown in Fig. 1. The average PM2.5 concentration after burning was $741 \mu \mathrm{g} / \mathrm{m}^{3}$ and the PM2.5 concentrations ranged from 217 to $1580 \mu \mathrm{g} / \mathrm{m}^{3}$. The average SPM concentration after burning was $810 \mu \mathrm{g} / \mathrm{m}^{3}$ and the SPM concentrations ranged from 249 to $1670 \mu \mathrm{g} / \mathrm{m}^{3}$. The mean ratio of the concentrations of PM2.5 and SPM after burning in all of the sparkling fireworks was 0.890 , and the correlation coefficient between the PM2.5 and SPM concentrations after burning was $0.984(\mathrm{p}<0.01)$, as shown in Fig. 2.

The PM2.5 and SPM emissions per firework are shown in Fig. 3. The emissions were calculated from the total weight difference of all of the filters used in each experiment. The arithmetic means of the PM2.5 emissions per firework were $8.0 \mathrm{mg}$ for Brand A, $8.2 \mathrm{mg}$ for Brand B, $124 \mathrm{mg}$ for Brand C, $115 \mathrm{mg}$ for Brand D, $48.5 \mathrm{mg}$ for Brand $\mathrm{E}$ and $47.1 \mathrm{mg}$ for Brand $\mathrm{F}$. The arithmetic means of the SPM emissions per firework were $8.5 \mathrm{mg}$ for Brand A, $11.8 \mathrm{mg}$ for Brand B, $135 \mathrm{mg}$ for Brand C, $125 \mathrm{mg}$ for Brand D, $58.0 \mathrm{mg}$ for Brand $\mathrm{E}$ and $50.0 \mathrm{mg}$ for Brand F, respectively. The minimum and maximum PM2.5 emissions per firework were $6.5 \mathrm{mg}$ for Brand A and $151 \mathrm{mg}$ for Brand C. The minimum and maximum SPM emissions per firework were $7.1 \mathrm{mg}$ for Brand A and $160 \mathrm{mg}$ for Brand C. The mean ratio of PM2.5 emissions to SPM emissions in all sparkling fireworks was 0.878. The mean ratios were 0.947 for Brand A, 0.696 for Brand B, 0.836 for Brand C, 0.920 for Brand D, 0.917 for Brand $\mathrm{E}$ and 0.950 for Brand $\mathrm{F}$.

Table 2. PM2.5 and SPM concentrations in air samples before and after burning the sparkling fireworks

\begin{tabular}{ccccccc}
\hline & Sampling & \multicolumn{2}{c}{ PM2.5 $\left(\mu \mathrm{g} / \mathrm{m}^{3}\right)$} & & \multicolumn{2}{c}{$\mathrm{SPM}\left(\mu \mathrm{g} / \mathrm{m}^{3}\right)$} \\
\cline { 3 - 4 } \cline { 6 - 7 } & room & Before burning & After burning & & Before burning & After burning \\
\hline Brand A & 1 & $15.0 \pm 7.0$ & $266 \pm 34$ & & $15.3 \pm 6.5$ & $308 \pm 72$ \\
Brand B & 1 & $12.8 \pm 5.7$ & $274 \pm 23$ & & $15.3 \pm 4.9$ & $405 \pm 26$ \\
Brand C & 2 & $20.2 \pm 8.2$ & $1060 \pm 160$ & & $31.3 \pm 10.3$ & $1140 \pm 131$ \\
Brand D & 2 & $22.3 \pm 14.1$ & $1030 \pm 136$ & & $26.4 \pm 12.3$ & $1090 \pm 135$ \\
Brand E & 1 & $11.4 \pm 3.3$ & $1420 \pm 92$ & & $13.3 \pm 4.0$ & $1500 \pm 103$ \\
Brand F & 2 & $12.9 \pm 6.1$ & $394 \pm 37$ & & $18.4 \pm 6.2$ & $419 \pm 59$ \\
\hline All brands & - & $15.8 \pm 9.1$ & $741 \pm 459$ & & $20.0 \pm 10.3$ & $810 \pm 464$ \\
\hline
\end{tabular}

Note. The values show arithmetic means $\pm \mathrm{SD}(\mathrm{n}=6$ for Brand A-F and $\mathrm{n}=36$ for All brands). The volumes were $66 \mathrm{~m}^{3}$ for sampling room 1 and $126 \mathrm{~m}^{3}$ for sampling room 2 . The numbers of burned fireworks were two for the experiments in sampling room 1 and one for sampling room 2. 


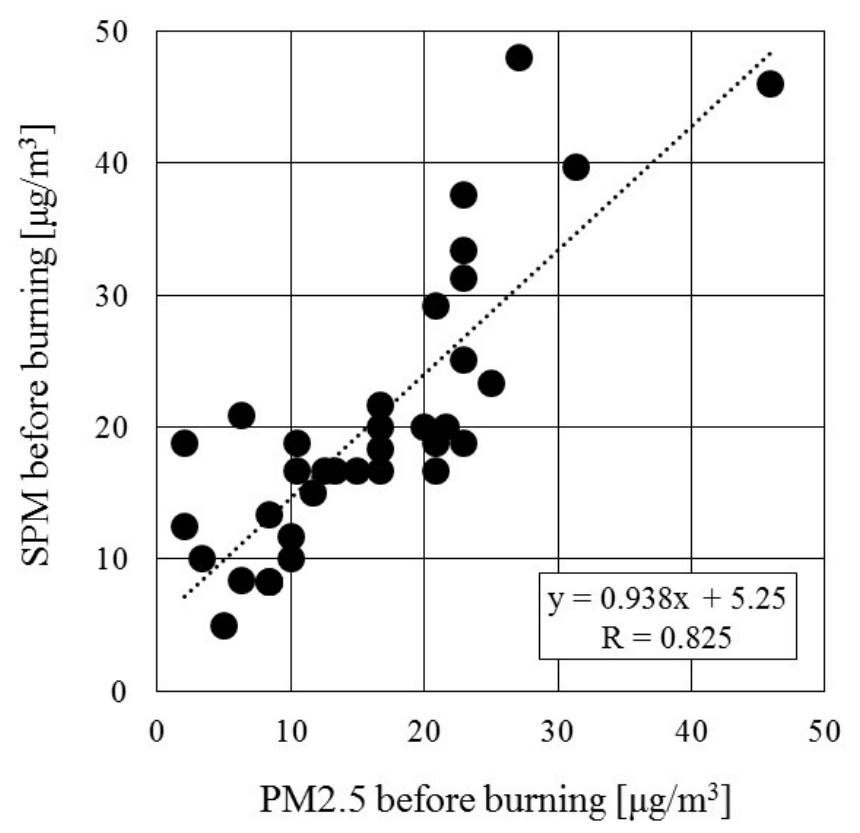

Figure 1. Relationship between PM2.5 and SPM in air samples before burning the sparkling fireworks

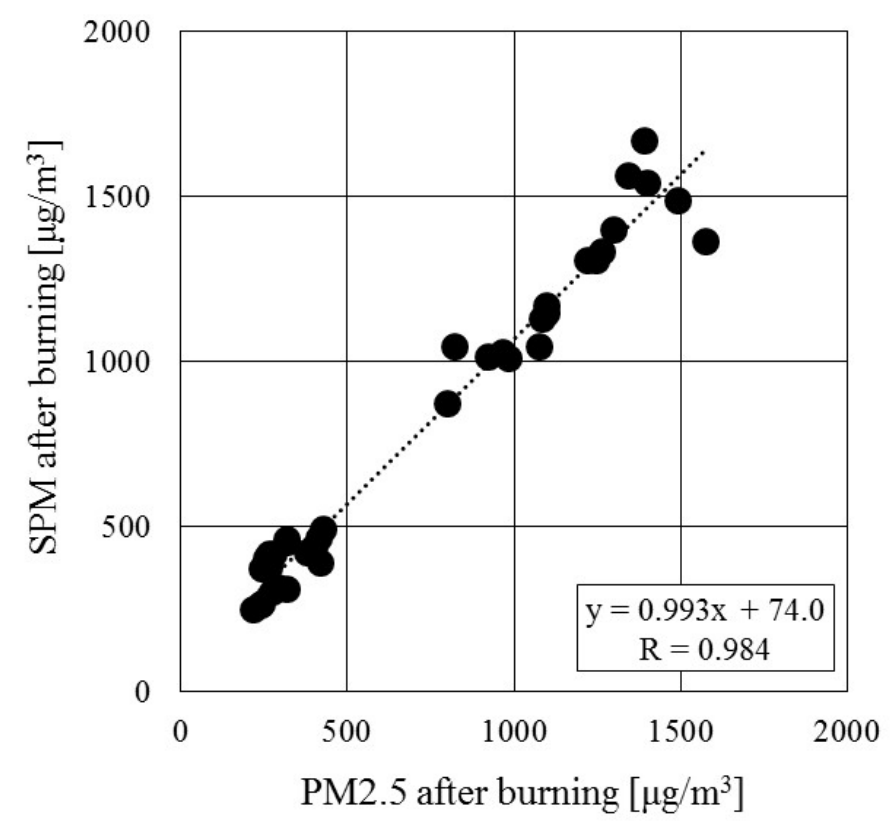

Figure 2. Relationship between PM2.5 and SPM in air samples after burning the sparkling fireworks 


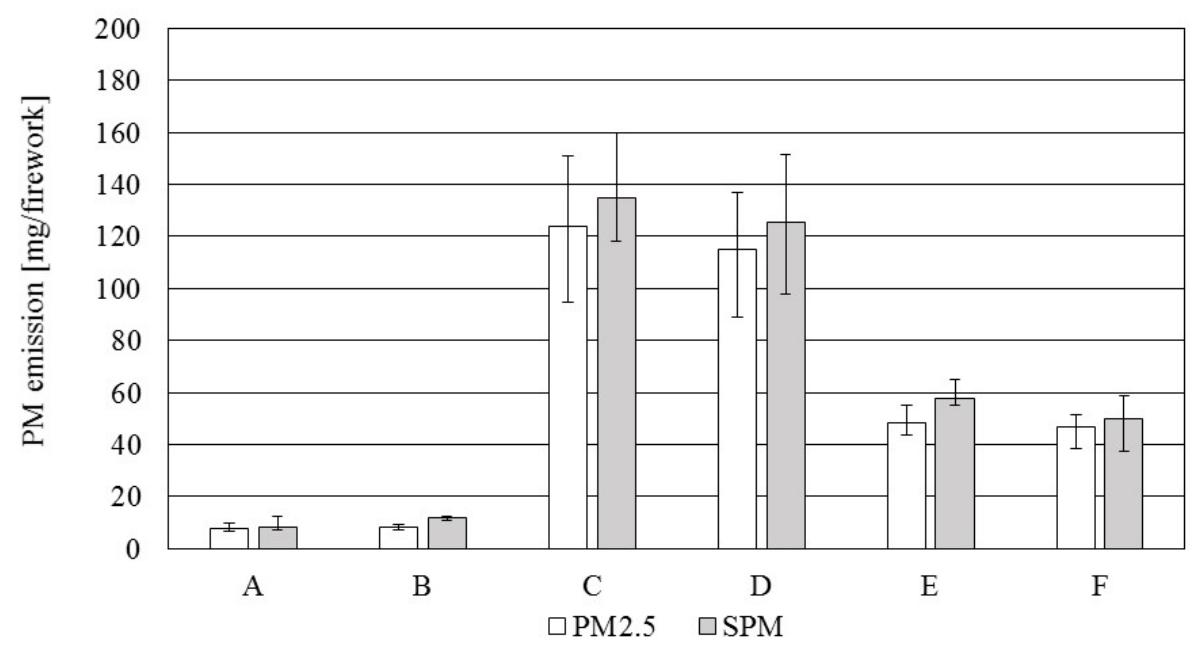

Figure 3. PM2.5 and SPM emissions per firework while burning the sparkling fireworks

Note. The numbers of PM emission data are six for each brand. The bars indicate the arithmetic mean values of the calculated PM emissions per firework. The ranges show that between minimum and maximum values.

To assess the influence of the combustible amount of the fireworks on PM2.5 and SPM emissions, the weights of the sparkling fireworks before and after burning were measured five times, and are shown in Table 1. The arithmetic means of the firework weight differences were $121 \mathrm{mg}$ for Brand A, $354 \mathrm{mg}$ for Brand B, $2080 \mathrm{mg}$ for Brand C, $2320 \mathrm{mg}$ for Brand D, $2640 \mathrm{mg}$ for Brand E and $2760 \mathrm{mg}$ for Brand F. The relationship between the means of the burning times and the means of the PM2.5 and SPM emissions of each firework are shown in Fig. 4. The relationship between the means of the weight differences and the means of the PM2.5 and SPM emissions of each firework are shown in Fig. 5. These correlation coefficients were not significant, which indicate that the burning time and the combustible amount did not influence PM2.5 and SPM emissions. The mean emissions per combustible amount ranged from 0.017 to $0.066 \mathrm{mg} / \mathrm{mg}$ for PM2.5, and from 0.018 to $0.071 \mathrm{mg} / \mathrm{mg}$ for SPM. The arithmetic means of the burning rates were $3.9 \mathrm{mg} / \mathrm{s}$ for Brand A, $5.2 \mathrm{mg} / \mathrm{s}$ for Brand B, $35.1 \mathrm{mg} / \mathrm{s}$ for Brand C, $71.6 \mathrm{mg} / \mathrm{s}$ for Brand D, $33.7 \mathrm{mg} / \mathrm{s}$ for Brand $\mathrm{E}$ and $63.0 \mathrm{mg} / \mathrm{s}$ for Brand F. The burning rates were calculated by dividing the means of the weight differences by the means of the burning times. The relationship between the means of the burning rates and the means of the PM2.5 and SPM emissions per firework are presented in Fig. 6 . PM2.5 and SPM emissions tended to increase with increased burning rates, which probably suggests that the burning rates of the fireworks influence these PM emissions.

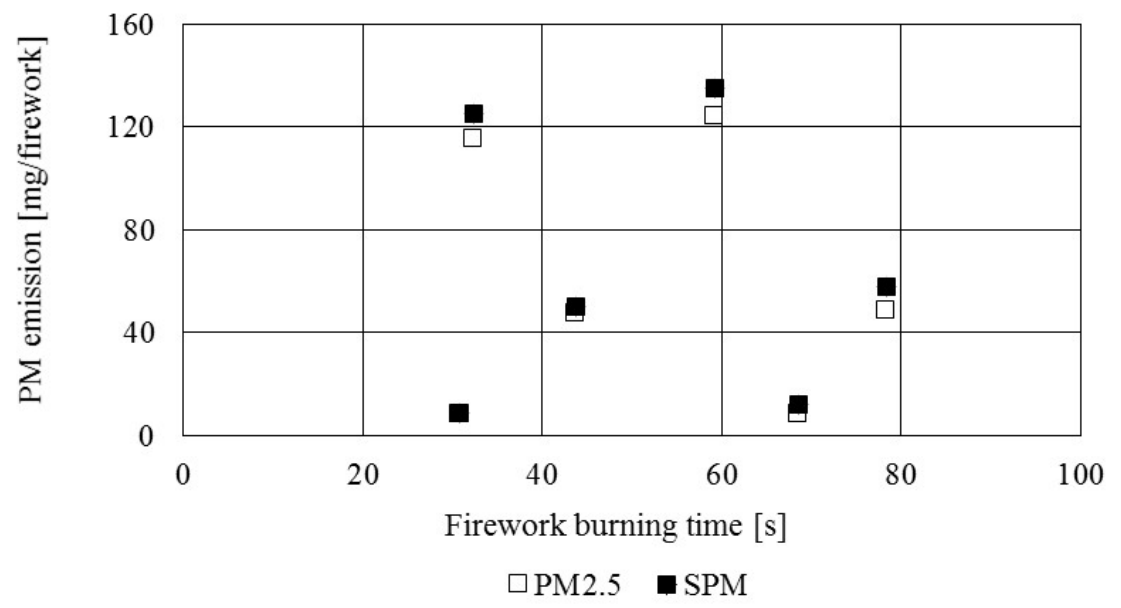

Figure 4. Relationships between firework burning times and PM emissions

Note. The arithmetic mean values of the firework burning times and those of the PM emissions per firework are plotted. 


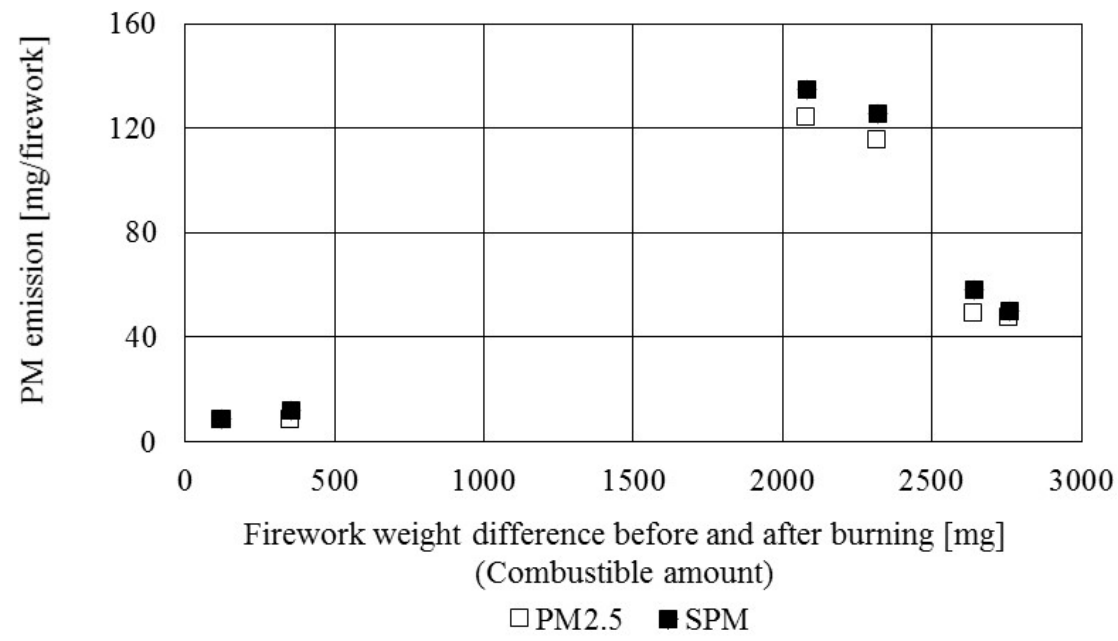

Figure 5. Relationships between firework weight differences before and after burning, and PM emissions

Note. The arithmetic mean values of the firework weight differences before and after burning the fireworks, and those of the PM emissions per firework are plotted.

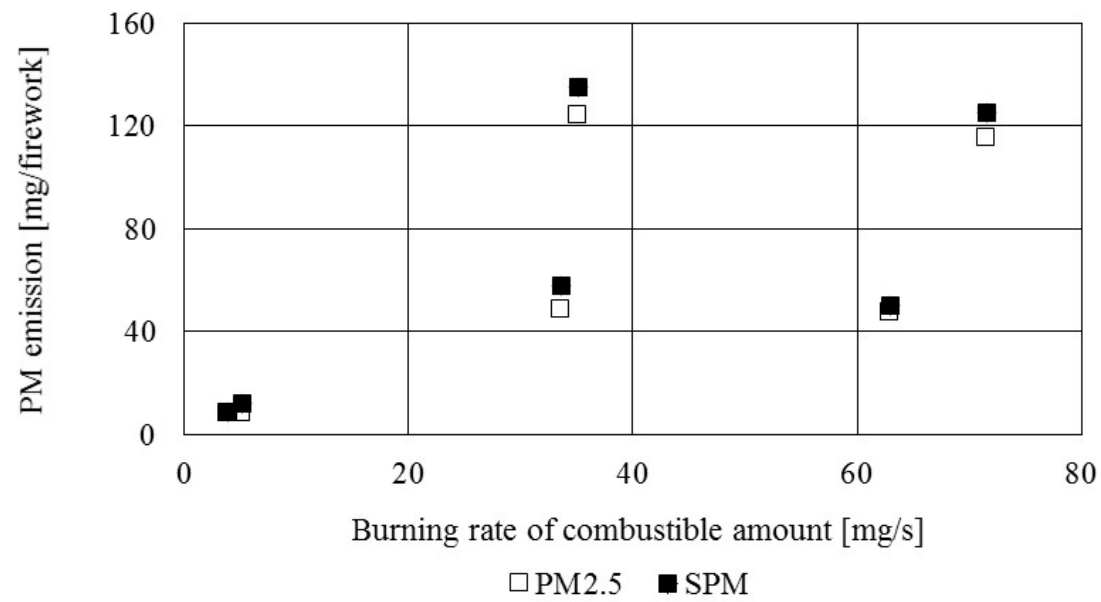

Figure 6. Relationships between burning rates of combustible amount and PM emissions

Note. The arithmetic mean values of the burning rates of combustible amount in the fireworks, and those of the PM emissions per firework are plotted.

\section{Conclusion}

The PM emissions of six brands of sparkling fireworks and their characteristics were investigated. PM2.5 and SPM were measured in the sampling rooms before and after burning the fireworks. The average concentrations before burning were $15.8 \mu \mathrm{g} / \mathrm{m} 3$ for PM2.5 and $20.0 \mu \mathrm{g} / \mathrm{m}^{3}$ for SPM. The mean ratio of the concentrations of PM2.5 and SPM was 0.801 . The average concentrations after burning were $742 \mu \mathrm{g} / \mathrm{m}^{3}$ for PM2.5 and $810 \mu \mathrm{g} / \mathrm{m}^{3}$ for SPM. The mean ratio of the concentrations of PM2.5 and SPM was 0.890 . The emissions per firework ranged from 6.5 to $151 \mathrm{mg}$ for PM2.5 and from 7.1 to $160 \mathrm{mg}$ for SPM. The means of the emissions per combustible amount of the firework ranged from 0.017 to $0.066 \mathrm{mg} / \mathrm{mg}$ for PM2.5, and from 0.018 to $0.071 \mathrm{mg} / \mathrm{mg}$ for SPM. It was investigated how much influence the burning time, burning rate and combustible amount of the fireworks on the PM emissions. The relationships between PM emissions and burning times and combustible amount of the fireworks were not significant. However, PM emissions tend to increase with the burning rates. This probably indicates that firework burning rates influence these PM emissions. Furthermore, studies are needed to investigate emission levels and characteristics of PM for many different kinds of fireworks. 


\section{Acknowledgments}

The author would like to thank Kindai University for providing the grant to complete this research. The author acknowledge the assistance given by Yusuke Ishiko and Soichiro Takeshita.

\section{References}

Ackermann-Liebrich, U., Leuenberger, P., Schwartz, J., Schindler, C., Monn, C., Bolognini, G., ... Zemp E. (1997). Lung function and long term exposure to air pollutants in Switzerland. American Journal for Respiratory Critical Care Medicine, 155, 122-129.

Barman, S. C., Singh, R., Negi, M. P. S., \& Bhargava, S. K. (2009). Fine particles (PM2.5) in ambient air of Lucknow city due to fireworks on Diwali festival. Journal Environmental Biology, 30(5), 625-632. Retrieved from http://www.jeb.co.in/journal_issues/200909_sep09/paper_01.pdf

Bi, X. H., Sheng, G. Y., Peng, P. A., Chen, Y. J., \& Fu, J. M. (2005). Size distribution of n-alkanes and polycycllic aromatic hydrocarbons (PAHs) in urban and rural atmospheres of Guangzhou. Atmospheric Environment, 39, 477-487. Retrieved from http://ac.els-cdn.com/S1352231004009409/1-s2.0-S1352231004009409-main.pdf?_tid=6097ebb4-c7df-11e 6-a6f6-00000aacb35d\&acdnat=1482367469_3bd9d029cad2a36d74dd947aae890309

Camilleri, R., \& Vella, A. J. (2010). Effect of fireworks on ambient air quality in Malta. Atmospheric Environment, 44, 4521-4527. Retrieved from http://ac.els-cdn.com/S1352231010006485/1-s2.0-S1352231010006485-main.pdf?_tid=b2c393de-c7df-11e 6-9785-00000aab0f27\&acdnat=1482367607_bb1f3eb7ea251414037e366076e51879

Du, Y., Xu, X., Chu, M., Guo, Y., \& Wang J. (2016). Air particulate matter and cardiovascular disease: the epidemiological, biomedical and clinical evidence. Journal of Thoracic Disease, 8(1), E8-E19. Retrieved from https://www.ncbi.nlm.nih.gov/pmc/articles/PMC4740122/

Environmental Protection Agency. (2013). Particulate Matter (PM) Standards - Table of Historical PM NAAQS. Retrieved from http://www.epa.gov/ttn/naaqs/standards/pm/s_pm_history.html

European Commission. (2016). Air Quality Standards - Environment - European Commission". Ec.europa.eu. Retrieved from http://ec.europa.eu/environment/air/quality/standards.htm

Gertler, A. W. (2005). Diesel vs. gasoline emissions: Does PM from diesel or gasoline vehicles dominate in the US?. Atmospheric Environment, 39, 2349-2355. Retrieved from http://ac.els-cdn.com/S1352231005000804/1-s2.0-S1352231005000804-main.pdf?_tid=195e300e-c7e0-11e 6-833c-00000aab0f26\&acdnat=1482367779_3dc058f7138845ab25d2e009e2418bef

Gomiscek, B., Frank, A., Puxbaum, H., Stopper, S., Preining, O., \& Hauck, H. (2004). Case study analysis of PM burden at an urban and a rural site during the AUPHEP project. Atmospheric Environment, 38, 3935-3948. Retrieved from http://ac.els-cdn.com/S1352231004003000/1-s2.0-S1352231004003000-main.pdf?_tid=5d84660e-c7e0-11e 6-b422-00000aab0f01\&acdnat=1482367893_413a305cd54b6cf84b07e0b4df589326

IARC. (2016). Outdoor Air Pollution, Vol. 109. IARC Monographs on the Evaluation of Carcinogenic Risks to Humans. Lyon, France: IARC, WHO.

Karagulian, F., Belis, C. A., Dora, C. F. C., Prüss-Ustün, A. M., Bonjour, S., Adair-Rohani, H., \& Amann, M. (2015). Contributions to cities' ambient particulate matter (PM): A systematic review of local source contributions at global level. Atmospheric Environment, 120, 475-483.

Mues, A., Manders, A., Schaap, M., van Ulft, L. H., van Meijgaard, E., \& Builtjes, P. (2013). Differences in particulate matter concentrations between urban and rural regions under current and changing climate conditions. Atmospheric Environment, 80, 232-247. Retrieved from http://ac.els-cdn.com/S1352231013005803/1-s2.0-S1352231013005803-main.pdf?_tid=cc61ccd6-d494-11e 6-b756-00000aacb35e\&acdnat=1483764803_c371ed11edd40c43cd6368dcadfa2dae

Pope, C. A., Burnett, R. T., Thun, M. J., Calle, E. E., Krewski, D., Ito, K., \& Thurston, G. D. (2002). Lung cancer, cardiopulmonary mortality, and long-term exposure to fine particulate air pollution. JAMA-Journal of American Medical Association, 287(9), 1132-1141.

Roosli, M., Theis, G., Künzli, N., Staehelin, J., Mathys, P., Oglesby, L., Camenzind, M., \& Braun-Fahrlander, Ch. (2001). Temporal and spatial variation of the chemical composition of PM10 at urban and rural sites in the Basel area, Switzerland. Atmospheric Environment, 35, 3701-3713. Retrieved from 
http://ac.els-cdn.com/S1352231000005112/1-s2.0-S1352231000005112-main.pdf?_tid=1e5e16b8-c7e1-11e 6-9446-00000aacb360\&acdnat=1482368217_eaffffd08f2ff51ec9e54c739b85a237

Seidel, D. J., \& Birnbaum, A. N. (2015). Effects of Independence Day fireworks on atmospheric concentrations of fine particulate matter in the United States. Atmospheric Environment, 115, 192-198. Retrieved from http://ac.els-cdn.com/S1352231015301369/1-s2.0-S1352231015301369-main.pdf?_tid=dd6a3674-d496-11e 6-9647-00000aacb35e\&acdnat=1483765690_5d4dc463cdc76f856abba52bf3375d9d

Srimuruganandam, B., \& Shiva Nagendra, S. M. (2012). Application of positive matrix factorization in characterization of PM10 and PM2.5 emission sources at urban roadside. Chemosphere, 88, 120-130. Retrieved from http://ac.els-cdn.com/S0045653512003116/1-s2.0-S0045653512003116-main.pdf?_tid=1d0f887e-d497-11e 6-8443-00000aacb35e\&acdnat=1483765797_66fb319f7561fd7970cf06e94639dc78

Vasilakos, Ch., Pateraki, S., Veros, D., Maggos, T., Michopoulos, J., Saraga, D., \& Helmis C. G. (2007). Temporal determination of heavy metals in PM2.5 aerosols in a suburban site of Athens, Greece. Journal of Atmospheric Chemistry, 57, 1-17. $\quad$ Retreived from http://link.springer.com/article/10.1007/s10874-006-9058-2

Vecchi, R., Bernardoni, V., Cricchio, D., D’Alessandro, A., Fermo, P., Lucarelli, F., Nava, S., Piazzalunga, A., \& Valli, G. (2008). The impact of fireworks on airborne particles. Atmospheric Environment, 42, 1121-1132. Retrieved from http://ac.els-cdn.com/S1352231007009685/1-s2.0-S1352231007009685-main.pdf?_tid=e715f59e-c7e1-11e 6-b422-00000aab0f01\&acdnat=1482368554_49f9135725f0711c90bf5248889c1418

Wang, Y., Zhuang, G., Xu, C., \& An, Z. (2007). The air pollution caused by the burning of fireworks during the lantern festival in Beijing. Atmospheric Environment, 41, 417-431. Retrieved from http://ac.els-cdn.com/S1352231006008351/1-s2.0-S1352231006008351-main.pdf?_tid=7c96f9ca-c7e1-11e 6-b138-00000aacb362\&acdnat=1482368375_7bd698ac103ef8c1ba1999957451cf51

Wehner, B., Wiedensohler, A., \& Heintzenberg, J. (2000). Submicrometer aerosol size distributions and mass concentration of the millennium fireworks 2000 in Leipzig, Germany. Journal of Aerosol Science, 31(12), 1489-1493.

Yin, J., \& Harrison, R. M. (2008). Pragmatic mass closure study for PM1.0, PM2.5 and PM10 at roadside, urban background and rural sites. Atmospheric Environment, 42, 980-988. Retrieved from http://ac.els-cdn.com/S1352231007008989/1-s2.0-S1352231007008989-main.pdf?_tid=aef1ae88-c7e1-11e 6-a6f6-00000aacb35d\&acdnat=1482368459_8e801f9b50a334aefbf8d6ec20d08d52

\section{Copyrights}

Copyright for this article is retained by the author(s), with first publication rights granted to the journal.

This is an open-access article distributed under the terms and conditions of the Creative Commons Attribution license (http://creativecommons.org/licenses/by/4.0/). 